\title{
Adrenergic Influence on Glucocounterregulation in Man
}

\author{
U. Lilavivat, R. G. Brodows, and R. G. Campbell \\ Endocrine-Metabolism Unit, Monroe Community Hospital, Endocrine-Metabolism Division, The Genesee Hospital, \\ and Department of Medicine, University of Rochester School of Medicine and Dentistry, Rochester, New York, USA
}

\begin{abstract}
Summary. To investigate the adrenergic role in glucocounterregulatory mechanisms, single-blind randomised studies were performed in 7 normal males during severe insulin-induced hypoglycaemia with or without adrenergic blockade. Intravenous phentolamine administration (5 mg stat and $0.5 \mathrm{mg}$ / min) did not interfere with the restoration of euglycaemia from hypoglycaemia. However, recovery of blood glucose in the presence of propranolol $(3 \mathrm{mg} /$ $3 \mathrm{~min}$ and $0.8 \mathrm{mg} / \mathrm{min}$ ) was retarded when compared with control studies (mean plasma glucose levels \pm $\mathrm{SEM}, 50 \pm 6 \mathrm{mg} / \mathrm{dl}$ versus $66 \pm 4 \mathrm{mg} / \mathrm{dl}$ at $120 \mathrm{~min}$ after insulin administration) despite appropriate glucagon, epinephrine, cortisol, and growth hormone responses. Plasma norepinephrine response was unaffected by propranolol but augmented threefold by phentolamine. Increases in plasma lactate, pyruvate and non-esterified fatty acids were blunted with propranolol while rebound non-esterified fatty acid was observed with phentolamine infusion. These data suggest that complete recovery of blood glucose from severe hypoglycaemia requires full sympathetic nervous system activity despite the integrity of other counterregulatory mechanisms.
\end{abstract}

Key words: Hypoglycaemia, adrenergic blockade, catecholamines, glucagon, cortisol, growth hormone, lactate, pyruvate, non-esterified fatty acids.

Glucose homeostasis under normal circumstances is mediated largely by insulin but, during hypoglycaemia, counterregulatory mechanisms become important. These include the release of catecholamines, glucagon, growth hormone, and cortisol, apparently triggered by a critical blood glucose level rather than the rate of fall in glucose concentration $[1,2]$. Many investigations have been focussed on the role of the sympathetic nervous system in glucose homeostasis, but there is no general agreement as to whether adrenergic mechanisms participate in the restoration of blood glucose in the face of glucopenia.
Propranolol, a $\beta$-adrenergic blocker, has been shown to retard glucose recovery from insulin-induced hypoglycaemia in man [3-5]. Lack of glucocounterregulation during 2-deoxy-D-glucose-induced intracellular glucopenia in adrenalectomised subjects [6] and in subjects where the sympathetic outflow is interrupted [7], supports the importance of adrenergic mechanisms in glucose homeostasis. However, doubt is cast on the essential role of adrenergic mechanisms in glucose recovery from insulin-induced hypoglycaemia by the finding that restoration of euglycaemia is unaffected in adrenalectomised subjects [8-11] or by adrenergic blocking agents [12-14] in the presence of other counterregulatory hormonal responses.

The present study was conducted to examine the influence of adrenergic mechanisms on the recovery from severe insulin-induced hypoglycaemia and on substrate mobilisation.

\section{Materials and Methods}

Seven healthy male subjects, aged $19-30$ years, within $10 \%$ of ideal body weight (Metropolitan Life Insurance Company Tables $1959), 60-82 \mathrm{~kg}$, participated in the study after giving informed consent, with the right to withdraw from the study. None were suffering from any illness or taking any medication during the study. The design of the study consisted of six experiments administering the following treatments: 1 ) insulin (bolus of $0.15 \mathrm{U} / \mathrm{kg}$ IV) and saline $(0.154 \mathrm{~mol} / \mathrm{l})$ infusion $(\mathrm{n}=7) ; 2)$ insulin and propranolol ( $3 \mathrm{mg}$ IV over $3 \mathrm{~min}$ then $0.8 \mathrm{mg} / \mathrm{min})(\mathrm{n}=7)$; 3 ) insulin and phentolamine ( $5 \mathrm{mg}$ IV stat then $0.5 \mathrm{mg} / \mathrm{min})(\mathrm{n}=5) ; 4)$ saline and propranolol $(\mathrm{n}=5) ; 5)$ saline and phentolamine $(\mathrm{n}=$ 4); 6) saline alone $(n=4)$. All experiments were conducted in a single blind, randomised fashion at 1 week intervals after overnight fasting. All subjects were instructed to comsume $300 \mathrm{~g}$ carbohydrate daily for 3 days prior to each experiment. At $0800 \mathrm{~h}$ indwelling $19 \mathrm{G}$ butterfly needles, kept patent with $0.154 \mathrm{~mol} / 1$ saline, were inserted via both antecubital veins. Subjects remained supine for at least $45 \mathrm{~min}$ before blood samples were obtained. After baseline sampling at -10 and $0 \mathrm{~min}$, crystalline insulin or sham injection with saline was given as an IV bolus via a contralateral indwelling needle. Where appropriate, propranolol or phentolamine infusion was commenced immediately before insulin administration. Sham infusion with saline was given in a similar fashion, and the volume of all solutions was kept constant. Blood pressure, pulse rate and subsequent blood samples were obtained 
Table 1. Comparison of plasma substrate and hormone responses (mean $\pm S E M$ ) to insulin-induced hypoglycaemia with or without adrenergic blockade in normal subjects

\begin{tabular}{|c|c|c|c|c|c|c|c|c|c|c|}
\hline Treatment & Time & Glucose & Lactate & Pyruvate & $\mu \mathrm{mol} / \mathrm{l}$ & $\begin{array}{l}\text { Epi- } \\
\text { nephrine } \\
\mathrm{pg} / \mathrm{ml}\end{array}$ & $\begin{array}{l}\text { Norepi- } \\
\text { nephrine } \\
\mathrm{pg} / \mathrm{ml}\end{array}$ & $\begin{array}{l}\text { Immuno- } \\
\text { reactive } \\
\text { glucagon } \\
\mathrm{pg} / \mathrm{ml}\end{array}$ & Cortisol & $\begin{array}{l}\text { Growth } \\
\text { hormone } \\
\mathrm{ng} / \mathrm{ml}\end{array}$ \\
\hline Insulin- & $0 \min$ & $91 \pm 3$ & $1.14 \pm 0.1$ & $0.068 \pm 0.004$ & $378 \pm 76$ & $30 \pm 8$ & $172 \pm 30$ & $81 \pm 8$ & $12.3 \pm 1.6$ & $1.2 \pm 0.05$ \\
\hline alone & peak/nadir & $25 \pm 3$ & $2.62 \pm 0.2$ & $0.135 \pm 0.011$ & $224 \pm 31$ & $945 \pm 125$ & $331 \pm 49$ & $258 \pm 43$ & $27.9 \pm 0.8$ & $48.8 \pm 7.0$ \\
\hline$(n=7)$ & $120 \mathrm{~min}$ & $66 \pm 4$ & $1.73 \pm 0.2$ & $0.102 \pm 0.009$ & $345 \pm 32$ & $76 \pm 13$ & $242 \pm 29$ & $105 \pm 18$ & $26.6 \pm 1.1$ & $38.5 \pm 16.7$ \\
\hline Insulin- & $0 \min$ & $91 \pm 4$ & $1.09 \pm 0.1$ & $0.068 \pm 0.011$ & $379 \pm 54$ & $26 \pm 9$ & $151 \pm 29$ & $83 \pm 9$ & $13.2 \pm 1.4$ & $1.5 \pm 0.1$ \\
\hline propranolol & peak/nadir & $24 \pm 1$ & $1.52 \pm 0.1^{\mathrm{d}}$ & $0.105 \pm 0.012$ & $174 \pm 15$ & $1905 \pm 149^{d}$ & $282 \pm 32$ & $260 \pm 58$ & $30.9 \pm 2.2$ & $68.5 \pm 8.8^{\mathrm{c}}$ \\
\hline$(n=7)$ & $120 \mathrm{~min}$ & $50 \pm 6^{\mathrm{a}}$ & $1.18 \pm 0.1^{b}$ & $0.072 \pm 0.009$ & $182 \pm 29^{c}$ & $356 \pm 114^{b}$ & $190 \pm 30$ & $177 \pm 30^{c}$ & $28.3 \pm 2.5$ & $62.8 \pm 9.8^{c}$ \\
\hline Insulin- & $0 \mathrm{~min}$ & $93 \pm 2$ & $0.98 \pm 0.1$ & $0.067 \pm 0.008$ & $338 \pm 28$ & $25 \pm 13$ & $161 \pm 40$ & $72 \pm 8$ & $12.9 \pm 2.3$ & $1.4 \pm 0.3$ \\
\hline phentolamine & peak/nadir & $26 \pm 3$ & $2.67 \pm 0.4$ & $0.150 \pm 0.011$ & $193 \pm 27$ & $1073 \pm 249$ & $913 \pm 188^{c}$ & $203 \pm 38$ & $28.1 \pm 0.8$ & $36.5 \pm 5.7$ \\
\hline$(\mathrm{n}=5)$ & $120 \mathrm{~min}$ & $71 \pm 3$ & $1.82 \pm 0.4$ & $0.099 \pm 0.066$ & $575 \pm 105^{\mathrm{a}}$ & $149 \pm 38$ & $800 \pm 139^{c}$ & $103 \pm 18$ & $23.4 \pm 1.8$ & $21.0 \pm 3.8^{\mathrm{b}}$ \\
\hline
\end{tabular}

${ }^{\mathrm{a}} \mathrm{p}<0.05 ;{ }^{\mathrm{b}} \mathrm{p}<0.025 ;^{\mathrm{c}} \mathrm{p}<0.01 ;{ }^{\mathrm{d}} \mathrm{p}<0.005$. P values represent significance of difference from studies with insulin alone by paired $\mathrm{t}$-test

at $10 \mathrm{~min}$ intervals for the first hour and at $15 \mathrm{~min}$ intervals for the second hour. Additional blood samples $(0.3 \mathrm{ml})$ were obtained at 5-min intervals during the first hour for glucose determinations with a Beckman glucose analyser.

Blood for catecholamines was collected in chilled heparinised tubes containing reduced glutathione and EGTA, for glucagon in tubes containing $500 \mathrm{KIU}$ of trasylol (FBA Pharmaceuticals, Leverkusen-Bayerwerk, West Germany) and EDTA $(1.5 \mathrm{mg} / \mathrm{ml}$ of blood) and for growth hormone and cortisol in heparinised tubes. Plasma was separated after refrigerated centrifugation and kept frozen until analysed. Catecholamine levels were determined by radioenzymatic assay [15] with modification [2]. The intra- and interassay coefficients of variation were less than $10 \%$ at the range of concentration reported in the Result Section, and the sensitivity of the assay based on twice the blank count varied between $5-10 \mathrm{pg} / \mathrm{ml}$. Plasma glucagon levels were determined on acetone extracts of plasma [12] by radioimmunoassay using $30 \mathrm{~K}$ antiserum [16]. The intra- and interassay coefficients of variation were within $5 \%$ at the level of $300 \mathrm{pg} / \mathrm{ml}$. The sensitivity of the assay was $50 \mathrm{pg} / \mathrm{ml}$. Measurement of growth hormone was performed by radioimmunoassay kit from Kallestad Laboratories (Chaska MN), and a radioimmunoassay kit from Diagnostic Products (Los Angeles CA) was used for plasma cortisol assay. Plasma was stored at $-20^{\circ} \mathrm{C}$ for non-esterified fatty acid (NEFA) $[17,18]$ and lactate [19] determination. Aliquots of plasma were immediately deproteinised with $3 \mathrm{~mol} / \mathrm{l}$ perchloric acid and supernatant was frozen at $-70^{\circ} \mathrm{C}$ until assayed for pyruvate [20], of which there was no detectable degradation within 3 months of storage.

The results were expressed as mean \pm SEM and significance of difference between the means was determined by Student's paired t-test. Significance of overall difference in each variable between experiments was determined by twoway Anovar with the interaction of two trial factors, treatment and time, using P2V program, BMDP-1977, University of California.

\section{Results}

Following IV insulin alone, systolic blood pressure increased significantly from $103 \pm 4 \mathrm{mmHg}$ to $122 \pm$ $6 \mathrm{mmHg}$, while diastolic blood pressure declined from $73 \pm 4 \mathrm{mmHg}$ to $59 \pm 4 \mathrm{mmHg}$, with a rise in pulse rate from $58 \pm 2$ beats/min to $80 \pm 6$ beats/ $\min$ at $30 \mathrm{~min}(\mathrm{p}<0.005)$. Following insulin-propranolol, there were increases in both systolic and diastolic blood pressure from $104 \pm 5 \mathrm{mmHg}$ to 116 $\pm 5 \mathrm{mmHg}$, and $75 \pm 3 \mathrm{mmHg}$ to $84 \pm 4 \mathrm{mmHg}$ at $30 \mathrm{~min}$ respectively $(\mathrm{p}<0.01$ ), but pulse rate remained at $54 \pm 2$ beats/min. Insulin-phentolamine similarly raised systolic blood pressure to $115 \pm$ $9 \mathrm{mmHg}$ but markedly decreased diastolic blood pressure from $71 \pm 2 \mathrm{mmHg}$ to $48 \pm 2 \mathrm{mmHg}$ at $30 \mathrm{~min}$ ( $\mathrm{p}<0.01)$, and pulse rate rose from $58 \pm$ 3 beats $/ \mathrm{min}$ to $106 \pm 10$ beats $/ \mathrm{min}(\mathrm{p}<0.01)$. The comparison of the metabolic substrate and hormonal responses with or without adrenergic blockade is summarised in Table 1.

\section{Insulin Alone}

After insulin alone (Fig. 1), plasma glucose level declined from $91 \pm 3 \mathrm{mg} / \mathrm{dl}$ to a nadir of $25 \pm 3 \mathrm{mg} /$ $\mathrm{dl}$ at $25 \mathrm{~min}$; it then rose abruptly by $40 \mathrm{~min}$ and subsequently reached $66 \pm 4 \mathrm{mg} / \mathrm{dl}$ at $120 \mathrm{~min}$. Baseline plasma epinephrine concentration was $30 \pm$ $8 \mathrm{pg} / \mathrm{ml}$; it had risen significantly by $30 \mathrm{~min}(\mathrm{p}<$ $0.01)$ and reached a peak level of $945 \pm 125 \mathrm{pg} / \mathrm{ml}(\mathrm{p}$ $<0.0005$ ) at $40 \mathrm{~min}$. Plasma norepinephrine was 172 $\pm 30 \mathrm{pg} / \mathrm{ml}$ initially, rising significantly to levels of $225 \pm 39 \mathrm{pg} / \mathrm{ml}$ by $20 \mathrm{~min}(\mathrm{p}<0.01)$, and achieving peak levels of $331 \pm 49 \mathrm{pg} / \mathrm{ml}$ at $40 \mathrm{~min}$. Its level remained elevated through the whole 120 minutes of study. Plasma glucagon concentration increased by 30 min $(\mathrm{p}<0.005)$ from the baseline level of $81 \pm$ $8 \mathrm{pg} / \mathrm{ml}$ and reached $258 \pm 43 \mathrm{pg} / \mathrm{ml}(\mathrm{p}<0.0025)$ at $40 \mathrm{~min}$. Plasma cortisol rose by $40 \mathrm{~min}(\mathrm{p}<0.01)$ from $12.3 \pm 1.6 \mu \mathrm{g} / \mathrm{dl}$ and attained the level of 27.6 $\pm 1.5 \mu \mathrm{g} / \mathrm{dl}$ at $60 \mathrm{~min}(\mathrm{p}<0.0005)$. Plasma growth hormone increased from baseline level of $1.2 \pm$ $0.05 \mathrm{ng} / \mathrm{ml}$ to $14.9 \pm 5.2 \mathrm{ng} / \mathrm{ml}$ and $48.8 \pm 7.0 \mathrm{ng} / \mathrm{ml}$ at $40 \mathrm{~min}(\mathrm{p}<0.05)$ and $60 \mathrm{~min}(\mathrm{p}<0.001)$ respectively, and remained elevated throughout $120 \mathrm{~min}$.

Figure 2 illustrates changes of plasma lactate, pyruvate, and NEFA following IV insulin with and without $\beta$-adrenergic blockade. After insulin alone, 

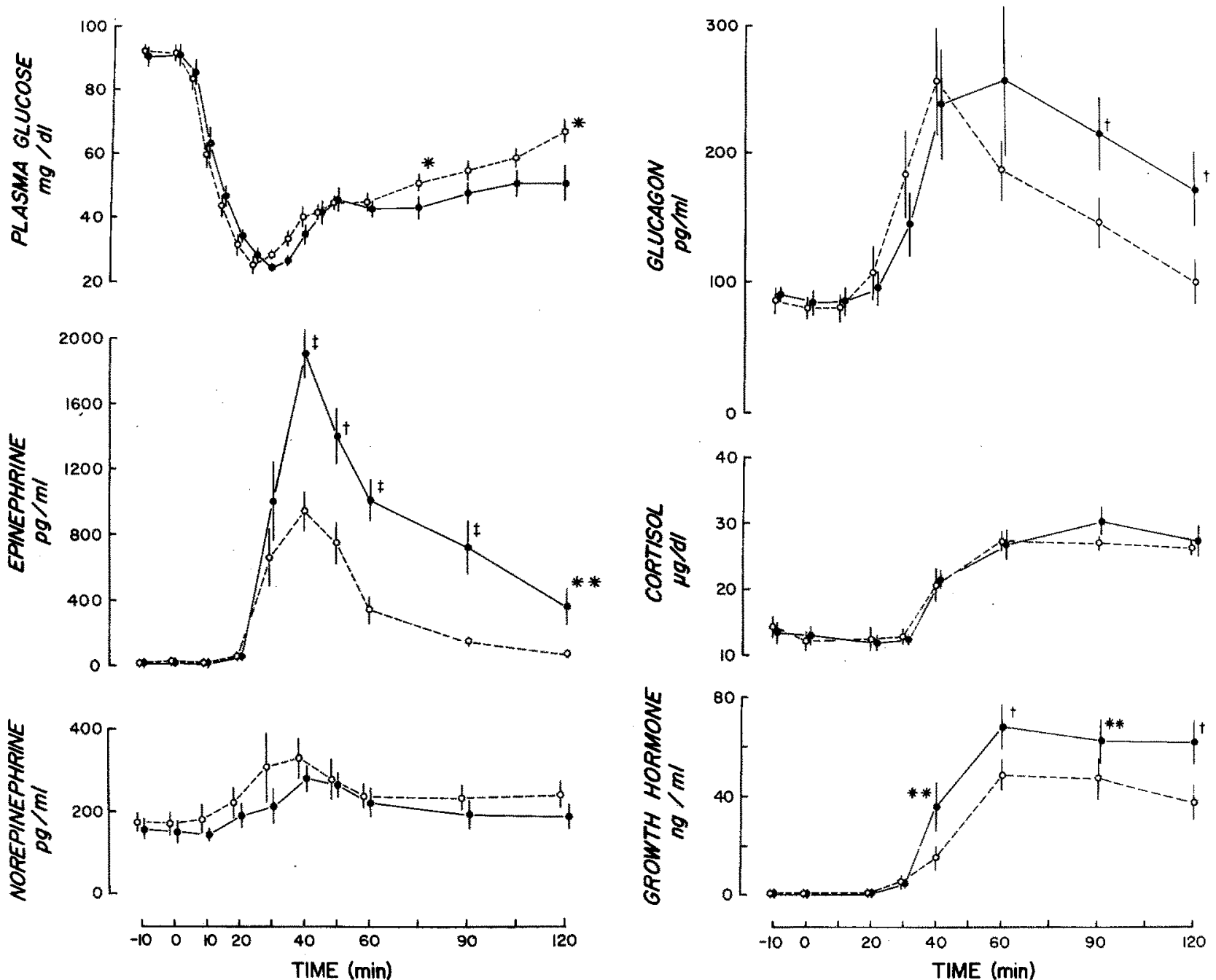

Fig. 1. Plasma glucose, epinephrine, norepinephrine, glucagon, cortisol, and growth hormone levels (mean \pm SEM) following insulin $0.15 \mathrm{U} / \mathrm{kg}$ IV with continuous saline $\left(--\mathrm{O}_{-}--\right)$or propranolol $(3 \mathrm{mg} / 3 \mathrm{~min}, 0.8 \mathrm{mg} / \mathrm{min} ; \longrightarrow-$ infusion in 7 normal male subjects. ${ }^{*} \mathrm{p}<0.05 ; * \mathrm{p}<0.025 ;+\mathrm{p}<0.01 ; \neq \mathrm{p}<0.005$. ( $\mathrm{p}$ values represent significance of differences between saline vs propranolol by paired t-test)

plasma lactate concentration rose from $1.14 \pm$ $0.1 \mathrm{mmol} / \mathrm{l}$ to $1.48 \pm 0.11 \mathrm{mmol} / 1$ by $20 \mathrm{~min}(\mathrm{p}<$ $0.005)$ and $2.62 \pm 0.2 \mathrm{mmol} / 1$ at $60 \mathrm{~min}(\mathrm{p}<$ $0.0025)$. Plasma pyruvate increased from the baseline level of $0.068 \pm 0.004 \mathrm{mmol} / 1$ to $0.135 \pm$ $0.01 \mathrm{mmol} / 1$ at $60 \mathrm{~min}(\mathrm{p}<0.0025)$, while the lactate/pyruvate ratio did not significantly change. Plasma NEFA levels declined from the baseline level of $378 \pm 76 \mu \mathrm{mol} / 1$ to $224 \pm 31 \mu \mathrm{mol} / 1$ by $20 \mathrm{~min}$ $(\mathrm{p}<0.025)$ then subsequently rose towards baseline values.

\section{Insulin and Propranolol}

During insulin-propranolol (Fig. 1), plasma glucose declined to a nadir comparable to that found with insulin alone. Recovery of plasma glucose levels from 75 to $120 \mathrm{~min}$ was, however, retarded, being only 50 $\pm 6 \mathrm{mg} / \mathrm{dl}$ at $120 \mathrm{~min}(\mathrm{p}<0.05$, by paired t-test $)$. Plasma glucose response from $60 \mathrm{~min}$ to $120 \mathrm{~min}$ was significantly different from the control $(F=6.52$, $\mathrm{p}<0.001$ ). During the first $20 \mathrm{~min}$ following administration of propranolol, plasma epinephrine was unaffected, but the subsequent response from 40 to $120 \mathrm{~min}$ was approximately 2 - to 3 -fold of control. The overall epinephrine responses between control and propranolol were significantly different $(\mathrm{F}=$ $5.62, \mathrm{p}<0.0001$ ). Plasma norepinephrine responses were, in contrast, not significantly affected. The increment in plasma glucagon was unaffected but the recovery of glucagon level was significantly delayed $(p<0.01)$. Plasma cortisol responses were virtually unaffected by propranolol but growth hormone response was augmented significantly. During insulin-propranolol, plasma lactate response was markedly decreased (Fig. 2). Pyruvate response was also 


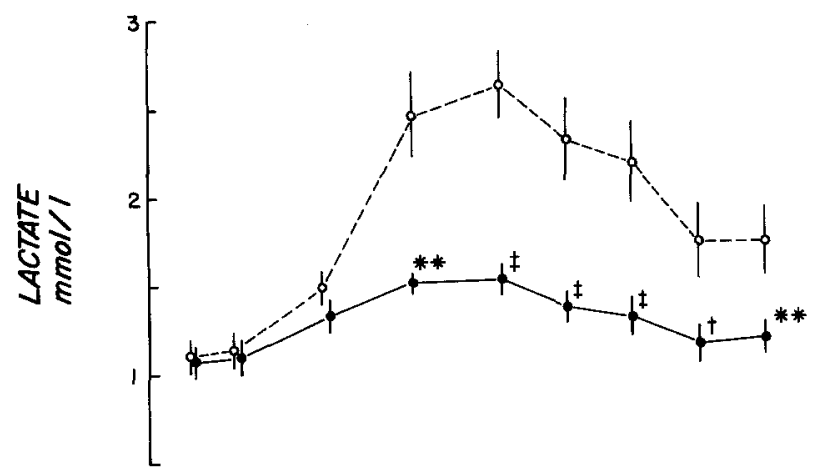

were not statistically altered by $\alpha$-blockade, while the growth hormone response was significantly smaller only at $120 \mathrm{~min}(\mathrm{p}<0.025)$. The responses of plasma lactate, pyruvate and NEFA levels are shown in Figure 4. The lactate and pyruvate responses were unchanged between the experiments. However, with phentolamine, NEFA levels promptly recovered by $40 \mathrm{~min}$ as compared to saline, and maintained this level throughout the $120 \mathrm{~min}(\mathrm{~F}=5.14$, $\mathrm{p}<0.004)$.

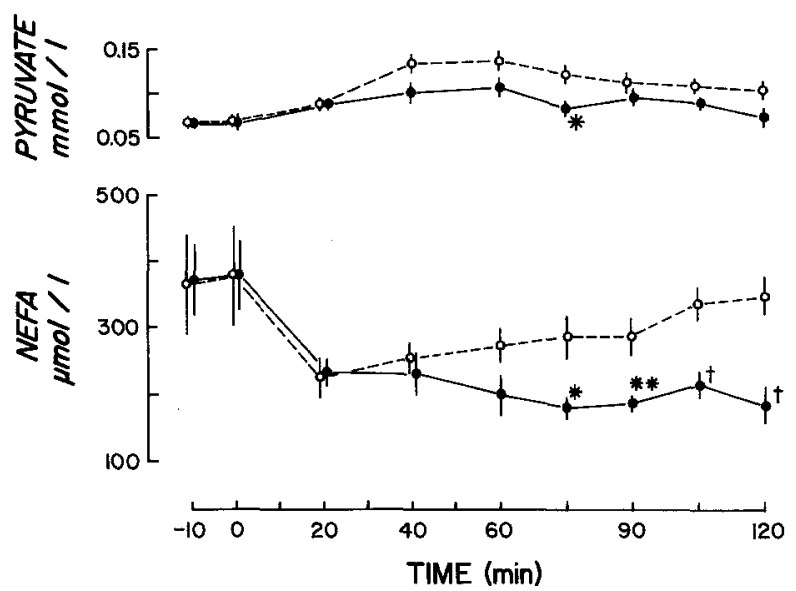

\section{Saline, Propranolol, and Phentolamine Alone}

Saline infusion alone for 2 hours did not significantly affect the levels of any metabolic substrates and hormones measured. Either blockade alone did not affect plasma glucose, lactate, pyruvate, NEFA, glucagon, cortisol, growth hormone and epinephrine levels, with the exception that after propranolol administration, growth hormone rose to $6.6 \pm$ $1.9 \mathrm{ng} / \mathrm{ml}(\mathrm{p}<0.06)$ at $120 \mathrm{~min}$. Following propranolol infusion there was transient and modest increase in norepinephrine concentration from 50 to 90 min when compared to baseline levels, but the overall responses were not significantly different from saline alone $(F=1.56, \mathrm{p}>0.1)$. After phentolamine infusion, plasma norepinephrine rose significantly by $10 \mathrm{~min}$ to a level of $255 \pm 65 \mathrm{pg} / \mathrm{ml} \mathrm{(p<}$ $0.05)$ and continued to increase to a level of $932 \pm$ $354 \mathrm{pg} / \mathrm{ml}$ at $120 \mathrm{~min}$. Its overall measurements were significantly different from saline alone $(F=4.97$, $\mathrm{p}<0.0005$ ).

significantly less than control $(F=2.33, p<0.03)$, but the difference was significant by paired t-test only at $75 \mathrm{~min}$. Plasma NEFA levels declined following insulin administration and remained suppressed with propranolol infusion compared to saline alone $(\mathrm{F}=4.19, \mathrm{p}<0.0007)$.

\section{Insulin and Phentolamine}

Comparison of plasma glucose, epinephrine, norepinephrine, glucagon, cortisol, and growth hormone responses following IV insulin with and without $\alpha$-adrenergic blockade are shown in Figure 3. Plasma glucose levels fell to similar values with and without $\alpha$-blockade and there was no significant difference in the rate of recovery $(F=1.3, p>0.3)$. There was no difference in the magnitude of the epinephrine response, but the recovery of epinephrine was significantly retarded with phentolamine treatment. In contrast, sustained elevation of norepinephrine level was observed throughout the phentolamine infusion period $(\mathrm{F}=15.77, \mathrm{p}<$ 0.0001). Plasma cortisol and glucagon responses

\section{Discussion}

The present study shows that blood glucose recovery from severe insulin-induced hypoglycaemia is re-tarded by $\beta$-adrenergic blockade with propranolol despite appropriate counterregulatory hormonal responses. This finding, in agreement with previous reports, both in animals $[21,22]$ and in man $[3-5,23$, $24]$ supports the concept that $\beta$-adrenergic mechanisms play an important role in the acute restoration of euglycaemia following hypoglycaemia. It is, however, important to recognise that propranolol does not completely prevent a compensatory rise in plasma glucose levels, possibly due to the availability of glucagon. Furthermore, as shown in the present study, the return of glucagon levels toward baseline during the recovery period was delayed, perhaps responding to the sluggish increase in plasma glucose toward baseline. Without such a compensatory response, glucose recovery could have been even further impaired. Other investigations have shown that somatostatin inhibition of glucagon secretion during hypoglycaemia decreased glucose production 

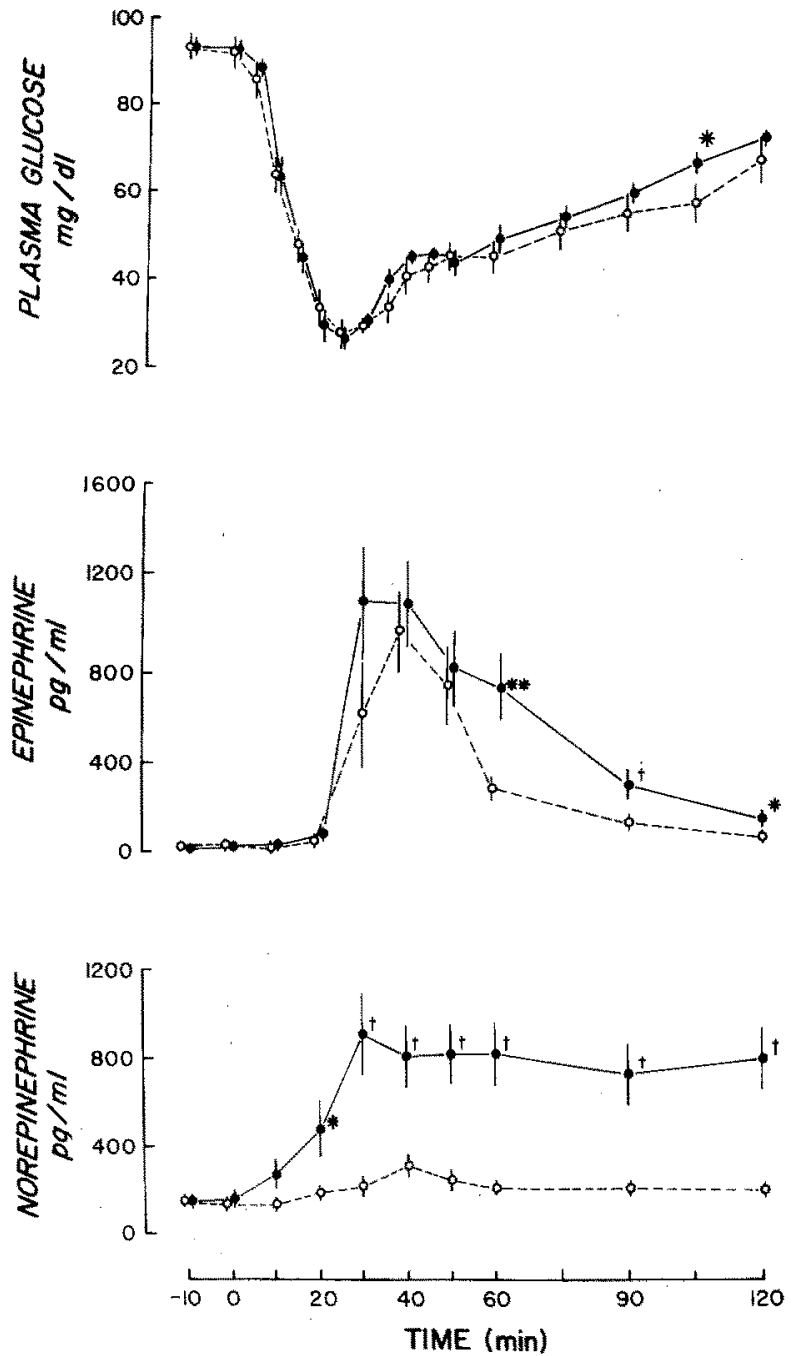
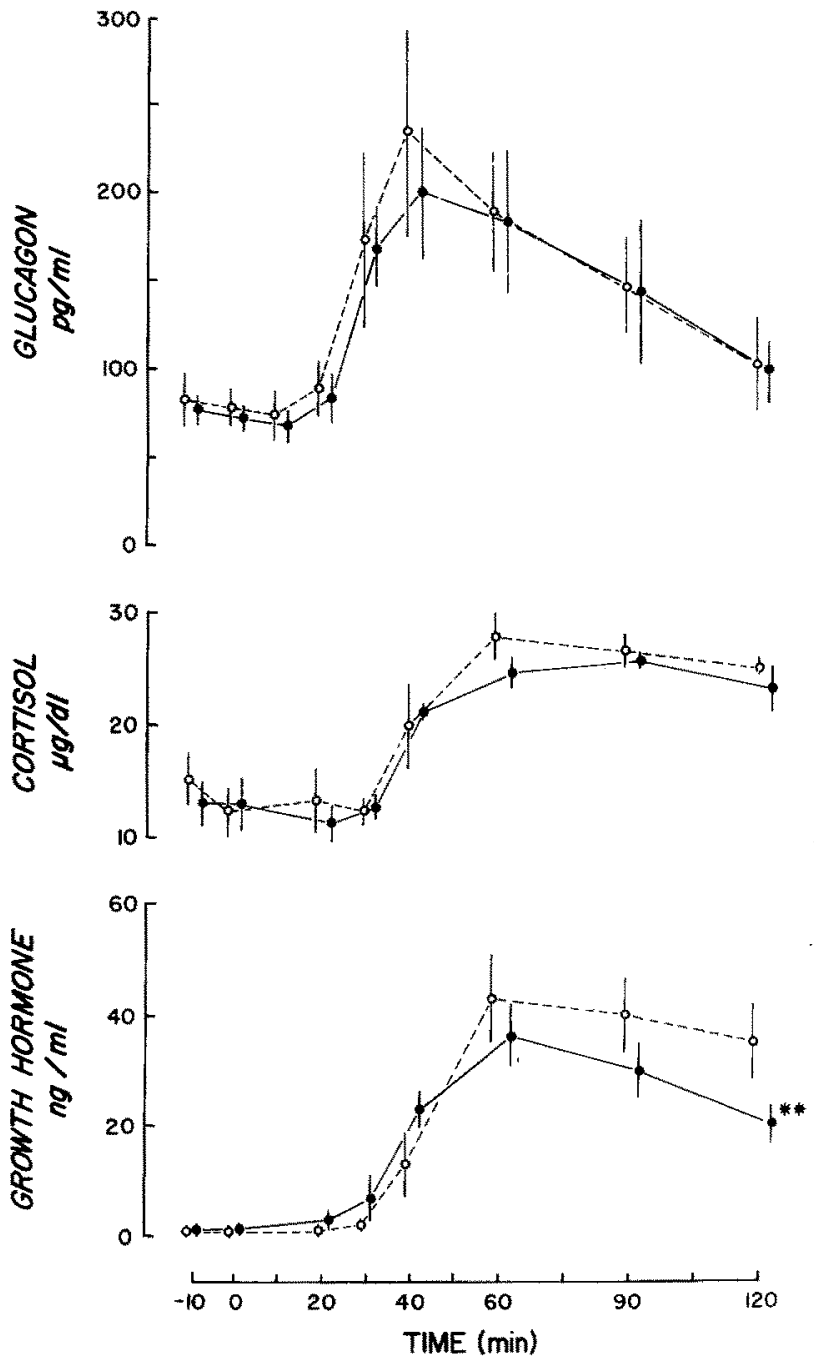

Fig. 3. Plasma glucose, epinephrine, norepinephrine, glucagon, cortisol, and growth hormone levels (mean \pm SEM) following insulin $0.15 \mathrm{U} / \mathrm{kg}$ IV with continuous saline $(---\mathrm{O}---)$ or phentolamine $(5 \mathrm{mg}$ stat, $0.5 \mathrm{mg} / \mathrm{min} ; \longrightarrow \longrightarrow$ ) infusion in $5 \mathrm{normal} \mathrm{male}$ subjects. ${ }^{*} \mathrm{p}<0.05 ; * \mathrm{p}<0.025 ; \dagger \mathrm{p}<0.01$. ( $\mathrm{p}$ values represent significance of differences between saline vs phentolamine by paired t-test)

and subsequently led to a delayed rise in glucose [14, 25 ]. The reason that other groups have failed to show an effect of adrenergic blockers, either $\beta$-adrenergic alone $[12,13]$, or combined $\beta$ - and $\alpha$-adrenergic blockers [14], on plasma glucose recovery remains unclear. It is possible that in some of these latter studies, giving smaller doses of insulin, there was less profound hypoglycaemia, and the glucagon response alone was sufficient to normalise blood glucose. However, where more severe hypoglycaemia is produced, combined homeostatic mechanisms are necessary for the restoration of euglycaemia. In fact, impairment of glucose recovery was greater when combined adrenergic blockers were administered in addition to somatostatin inhibition of glucagon release than during somatostatin infusion alone [14]. Hypoglycaemia in the adrenalectomised subjects, whose glucagon release was suppressed by somatos- tatin, was also more profound when compared to that in the normal individuals receiving a similar treatment [25]. Therefore, these findings suggest that adrenergic mechanisms may indeed play a contributory role in immediate glucose counterregulation.

Enhancement of (stimulatory) epinephrine levels, but not of norepinephrine, associated with hypoglycaemia during propranolol treatment, is similar to the effect noted in the hypertensive subjects receiving metoprolol [26], while phentolamine infusion resulted predominantly in an increase in norepinephrine concentration. Thus, combined $\alpha$ - and $\beta$-adrenergic blockade during hypoglycaemia could account for increases observed in both epinephrine and norepinephrine [14] levels. The possible mechanism for increase in epinephrine levels during $\beta$-adrenergic blockade may be due to decreased epinephrine uptake, as propranolol has been shown to augment 

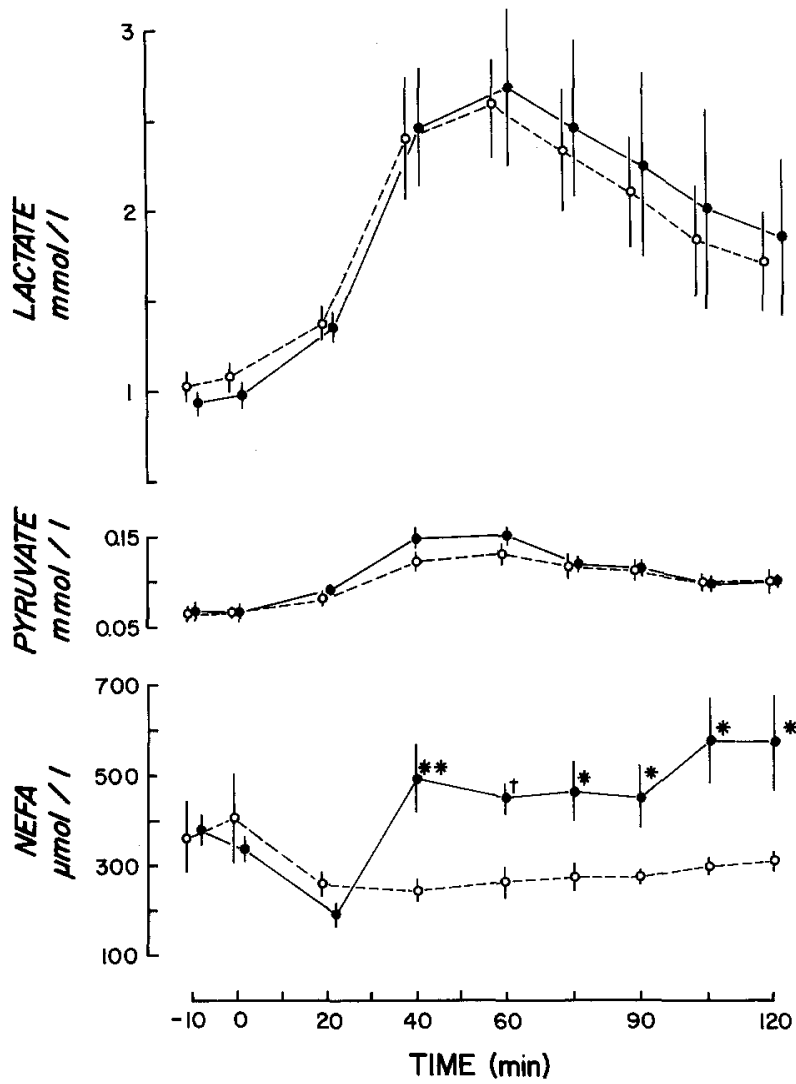

Fig. 4. Plasma lactate, pyruvate and NEFA levels (mean \pm SEM) following insulin $0.15 \mathrm{U} / \mathrm{kg}$ IV with continuous saline $(---\mathrm{O}--)$ or phentolamine $(5 \mathrm{mg}$ stat, $0.5 \mathrm{mg} / \mathrm{min}$; $\longrightarrow$ - infusion in 5 normal male subjects. $* \mathrm{p}<0.05 ; * \mathrm{p}<$ $0.025 ; \uparrow \mathrm{p}<0.01$. ( $\mathrm{p}$ values represent significance of differences between saline vs phentolamine by paired t-test)

the rise in plasma epinephrine concentration during exogenous epinephrine infusion [27]. However, the effect of propranolol on non-stimulatory epinephrine levels was not evident in our study.

Our data, in agreement with others $[3,4,28]$, suggest that mobilisation of lactate, pyruvate, and lipolysis are mediated by $\beta$-adrenergic receptors under enhanced sympathetic nervous system activity. Marked suppression of lactate, pyruvate, and NEFA mobilisation was observed in the presence of higher circulating epinephrine level. Although glucose turnover studies were not performed, lack of lactate and pyruvate substrate availability may decrease hepatic gluconeogenesis $[29,30]$, thereby impairing the restoration of blood glucose from hypoglycaemia. Since not all hepatic glucose output from gluconeogenesis is derived from lactate [31], impaired glucose recovery from shortage of this fuel can only be partial. It has also been suggested that NEFA can promote gluconeogenesis via the generation of acetyl CoA [32]. However, the higher NEFA level observed during hypoglycaemia accompanying $\alpha$-adrenergic blockade was not significantly associated with more rapid glucose recovery, suggesting that the latter pathway is less important in this event. Alternatively, hepatic NEFA uptake is in some way interfered with during $\alpha$-receptor blockade.

While insulin is by and large known to dominate the control of substrate economy, evidence both in vitro [33] and in vivo [34, 35] exists that growth hormone can promote lipolysis. Our data, showing a diversified response of growth hormone and NEFA following hypoglycaemia with adrenergic blockade, suggest that the mechanism for NEFA mobilisation under this circumstance is predominantly mediated by adrenergic activity. It has also been shown that growth hormone [36] and cortisol [37] can increase hepatic glucose output, but it is unlikely that such hormonal milieu are involved in the immediate counterregulatory function. Inhibition of growth hormone $[14,25,38]$ and cortisol $[38,39]$ responses during hypoglycaemia did not affect the restoration of blood glucose. Conversely, marked growth hormone and cortisol responses in sympathectomised subjects were not associated with substrate mobilisation during glucopenia $[6,7]$.

During counterregulation, the relationships of catecholamine response and glucose flux have been emphasised [40], but more recent studies show that the glucagon response precedes that of any other counterregulatory hormones [14]. It is noteworthy, however, that using a similar protocol, significant increments in norepinephrine preceding those of other hormonal responses were observed in our study. It has been thought that exogenous intravenous insulin itself may be responsible for such norepinephrine changes [2, 41]. Finally, hypoglycaemia by itself can initiate hepatic compensatory response, as increase in glucose output has been shown to occur independent of other regulatory mechanisms $[42,43]$.

Acknowledgements. The authors are indebted to Elaine L King, Kirti Bhatt, Kenneth Stabins, Christian Boetrich, Diane Nichols, and the Nursing Staff of the Clinical Research Center for their excellent technical assistance, and to Maggi Kingsley for her secretarial help.

This work was supported by grants from the American Diabetes Association, Inc; NIH-NIAMDD, AM21664, AM20494, and RR00044 from the Division of Research Facilities and Resources, and the Carroll $\mathrm{C}$ Colgan Fund.

\section{References}

1. DeFronzo RA, Andres R, Bledsoe TA, Faloona GA, Tobin JD (1977) A test of the hypothesis that the rate of fall in glucose concentration triggers counterregulatory hormonal responses. Diabetes 26: 445-452

2. Lilavivathana U, Brodows RG, Woolf PD, Campbell RG (1979) Counterregulatory hormonal responses during rapid glucose lowering in diabetic man. Diabetes 28: 873-877 
3. Abramson EA, Arky RA, Woeber KA (1966) Effects of propranolol on the hormonal and metabolic responses to insulininduced hypoglycaemia. Lancet II: 1386-1389

4. Abramson EA, Arky RA (1968) Role of beta-adrenergic receptors in counterregulation to insulin-induced hypoglycemia. Diabetes 17: 141-146

5. Deacon SP, Barnett D (1976) Comparison of atenolol and propranolol during insulin-induced hypoglycaemia. Br Med.J II: $272-273$

6. Brodows RG, Pi-Sunyer FX, Campbell RG (1975) Sympathetic control of hepatic glycogenolysis during glucopenia in man. Metabolism 24: 617-624

7. Brodows RG, Pi-Sunyer FX, Campbell RG (1973) Neural control of counterregulatory events during glucopenia in man. J Clin Invest 52: 1841-1844

8. Ginsburg J, Paton A (1956) Effects of insulin after adrenalectomy. Lancet II: $491-494$

9. von Euler US, Ikkos D, Luft R (1961) Adrenaline excretion during resting conditions and after insulin in adrenalectomised human subjects. Acta Endocrinol (Kbh) 38: 441-448

10. Ensinck JW, Walter RM, Palmer JP, Brodows RG, Campbell $\mathrm{RG}$ (1976) Glucagon responses to hypoglycemia in adrenalectomized man. Metabolism 25: 227-232

11. Brodows RG, Ensinck JW, Campbell RG (1976) Mechanism of plasma cyclic AMP response to hypoglycemia in man. Metabolism 25: 659-663

12. Walter RM, Dudl J, Palmer JP, Ensinck JW (1974) The effect of adrenergic blockade on the glucagon responses to starvation and hypoglycemia in man. J Clin Invest 54: 1214-1220

13. Clarke WL, Santiago JV, Thomas L, Ben-Galen E, Haymond MW, Cryer PE (1979) Adrenergic mechanisms in recovery from hypoglycemia in man: adrenergic blockade. Am J Physiol 236: E147-E152

14. Rizza RA, Cryer PE, Gerich JE (1979) Role of glucagon, catecholamines, and growth hormone in human glucose counterregulation. J Clin Invest 64: 62-71

15. Passon PG, Peuler JD (1973) A simplified radiometric assay for plasma norepinephrine and epinephrine. Anal Biochem 51: 618-631

16. Faloona GR, Unger RH (1974) Glucagon. In: Jaffe BM, Behrman HR (eds) Methods of hormone radioimmunoassay. Academic Press, New York, p 317-330

17. Trout DL, Estes Jr H, Friedberg SJ (1960) Titration of free fatty acids of plasma: a study of current methods and a new modification. J Lipid Res 1: 199-202

18. Baird JD, Black MW, Faulkner DE (1967) Semi-automated method for the determination of free fatty acids in plasma. $J$ Clin Pathol 20: 905-909

19. Hochella NJ, Weinhouse S (1965) Automated lactic acid determination in serum and tissue extracts. Anal Biochem 10: 304-317

20. Karl IE, Pagliara AS, Kipnis DM (1972) A microfluorometric enzymatic assay for the determination of alanine and pyruvate in plasma and tissues. J Lab Clin Med 80: 434-441

21. Palmieri GMA, Hawrylko J (1977) Enhancement by propranolol of insulin induced hypoglycemia in the chick. Clin Res 25: $623 \mathrm{~A}$

22. Brown JH, Riggilo DA (1968) Effect of sotalol (MJ 1999) and propranolol on insulin-induced hypoglycemia in the rat (32897). Proc Soc Exp Biol Med 127: 1158-1160

23. Kotler MN, Berman L, Rubenstein AH (1966) Hypoglycaemia precipitated by propranolol. Lancet II: 1389-1390

24. Newman RJ (1976) Comparison of propranolol, metoprolol, and acebutolol on insulin-induced bypoglycaemia. $\mathrm{Br}$ Med $\mathrm{J}$ II: $447-449$

25. Gerich J, Davis J, Lorenzi M, Rizza R, Bohannon N, Karam J, Lewis S, Kaplan R, Schultz T, Cryer PE (1979) Hormonal mechanism of recovery from insulin-induced hypoglycaemia in man. Am J Physiol 236: E380-E385
26. Hökfelt B, Hansson BG, Heding $\mathrm{LG}_{\text {, }}$, Nilsson KO (1978) Effect of insulin induced hypoglycaemia on the blood levels of catecholamines, glucagon, growth hormone, cortisol, C-peptide and proinsulin before and during mediation with the cardioselective beta-receptor blocking agent metoprolol in man. Acta Endocrinol (Kbh) 87: 659-667

27. Rizza RA, Cryer PE, Haymond MW, Gerich JE (1980) Adrenergic mechanisms for the effect of epinephrine on glucose production and clearance in man. $\mathrm{J}$ Clin Invest 65 : 682-689

28. Fredhold BB, Karlsson J (1970) Metabolic effects of prolonged sympathetic nerve stimulation in canine subcutaneous adipose tissue. Acta Physiol Scand 80: 567-576

29. Cori CF, Cori GT (1929) Glycogen formation in the liver from d- and l-lactic acid. J Biol Chern 81: 389-403

30. Krebs H (1964) Gluconeogenesis. The Croonian Lecture 1963. Proc R Soc Lond [Biol] 159: 545-564

31. Felig P (1973) The glucose-alanine cycle. Metabolism 22: 179-207

32. Ruderman NB, Toews CJ, Shafrir E (1969) Role of free fatty acids in glucose homeostasis. Arch Intern Med 123: 299-313

33. Fain JN, Kovacev VP, Scow RO (1965) Effect of growth hormone and dexamethasone on lipolysis and metabolism in isolated fat cells of the rat. J Biol Chem 210: 3522-3529

34. Raben MS, Hollenberg CH (1959) Effect of growth hormone on plasma fatty acids. $J$ Clin Invest $38: 484-488$

35. Felig P, Marliss EB, Cahill Jr GF (1971) Metabolic response to human growth hormone during prolonged starvation. J Clin Invest 50: 411-421

36. Exton JH, Mallette LE, Jefferson LS, Wang EHA, Friedman N, Miller TB, Park CR (1970) The hormonal control of hepatic gluconeogenesis. Recent Prog Horm Res 26: 411-455

37. Baxter J, Forsham P (1972) Tissue effect of glucocorticoids. Am J Med 53: 573-584

38. Feldman JM, Plonk JW, Bivens CH (1975) The role of cortisol and growth hormone in the counter-regulation of insulininduced hypoglycemia. Horm Metab Res 7: 378-381

39. Plonk JW, Bivens CH, Feldman JM (1974) Inhibition of hypoglycemia-induced cortisol secretion by the serotonin antagonist cyproheptadine. J Clin Endocrinol Metab 38: $836-840$

40. Garber AI, Cryer PE, Santiago JV, Haymond MCV, Pagliara AS, Kipnis DM (1976) The role of adrenergic mechanisms in the substrate and hormonal response to insulin-induced hypoglycemia in man. J Clin Invest 58: 7-15

41. Rowe JW, Young JB, Stevens A, Kilgore A, Pallotta J, Landsberg $\mathrm{L}$ (1979) Insulin increases plasma norepinephrine (NE) in man independent of changes in blood glucose. Clin Res 27: $594 \mathrm{~A}$

42. Hers HG (1976) The control of glycogen metabolism in the liver, Annu Rev Biochem 45: 167-189

43. Saccà L, Cryer PE, Sherwin RS (1979) Blood glucose regulates the effects of insulin and counterregulatory hormone on glucose production in vivo. Diabetes 28: 533-536

Received: May 30,1980 ,

and in revised form: November 21, 1980

Usah Lilavivat, M.D.

University of Rochester

School of Medicine and Dentistry

Endocrine-Metabolism Unit

Monroe Community Hospital

435 East Henrietta Road

Rochester, NY 14603

USA 